\title{
On Human Rights: \\ Premises for a New Approach to Fundamental Social Rights
}

Rodrigo Garcia Schwarz*

Universidade do Oeste de Santa Catarina (UNOESC) (Brazil)

doi: 10.7358/ecps-2016-013-garc

rgschwarz@gmail.com

\section{SUI DIRITTI UMANI: PREMESSE PER UN NUOVO APPROCCIO AI DIRITTI SOCIALI FONDAMENTALI}

\section{Abstract}

From the point of view of international law, what we are seeking in this paper is to expose some of the premises for a (new) approach to fundamental social rights. If we think about the absolute supremacy of human life, a life that, to be understood as such, must be a life lived with dignity, we have to think about life from a material point of view and, therefore, in a priority status to the so-called "social" rights, since social rights (economic, social and cultural) address issues as basic to life and human dignity as food, health, shelter, work, education and water. With this understanding, it becomes very clear that the materiality of human dignity rests on the so-called "existential minimum", the hard kernel of social rights, in such a way that social rights are genuine (true) fundamental human rights. Recognition of social rights cannot be, therefore, a mere listing of good intentions on the part of the state. Social rights are fundamental rights, which are for all men, can be exercised by everyone and are essential to life and human dignity. What we are seeking in this paper, then, is to shed light on the understanding that social rights are fundamental human rights in international law.

Keywords: Fundamental rights, Human rights, International law, Premises, Social rights.

* Brazilian Federal Judge, Doctor of Laws and Doctor in Social History, Professor J.S.D. in the LL.M. (Master of Laws) Program of the University of the West of Santa Catarina (UNOESC). 


\section{INTRODUCTION}

If we think about the absolute supremacy of human life, a life that, to be understood as such, must be a life lived with dignity, we have to think about life from a material point of view and, therefore, in a priority status to the so-called «social» rights, since social (economic, social and cultural) rights address issues as basic to life and human dignity as food, health, shelter, work, education and water. With this understanding, it becomes very clear that the materiality of human dignity rests on the so-called "existential minimum», the hard kernel of social rights, in such a way that social rights are genuine (true) fundamental human rights.

Recognition of social rights cannot be, therefore, a mere listing of good intentions on the part of the states in international law. Social rights are fundamental rights, which are for all men, can be exercised by everyone and are essential to life and human dignity. Nevertheless, that leaves much to be done so that these rights can be put on a par with civil and political rights insofar as legal status is concerned.

In this context, it is necessary to indicate the adoption of a new viewpoint on economic, social and cultural rights, or simply, «social rights», since the exercise of any human rights, even the traditional individual civil and politic rights, are intimately bound up with the notion of dignity and related to the freedom and autonomy of the individual, is not possible without a guarantee of the economically, socially and culturally dependent existential minimum.

This implies the need to address the process of trivialisation (which, in practice, strips human rights of their authority) and theoretical fragmentation of rights since the implementation of the social rights cannot be considered separately from the consolidation of democracy itself. The fulfilment of civic responsibilities, essential for democracy, requires economic and social reforms and the reshaping of mental attitudes for the effective removal of the obstacles that impede it.

To speak of human rights, then, is to speak of making social rights accessible to groups of people who do not usually have effective access to them. That is, this is a matter of opening up a new path, alternative and real in the true sense, leading to a non-exclusive citizenship that is democratic in the sense of its recognition by everyone and its all-inclusiveness and directed toward an authentically transformative praxis of society. To get this moving undoubtedly requires great energy and tenacity and the capacity to conceptualise content and techniques that allow reconsidering social rights and their guarantees. 


\section{INITIAL CONSIDERATIONS: ON HUMAN RIGHTS}

One of the great advances of modern social constitutionalism and international law is that it has bestowed upon the international legal status of human rights a binding power, a fact that makes the legal content itself of human rights compulsory supra-legal law, a fundamental axis generally with constitutional standing, to be applied by state officials and effectively honoured by private individuals. This being the case, beyond the complex legal debate over the relationship between international law and internal law - monism and dualism - it is true that, with more or less emphasis, modern constitutions contain clauses conferring special force on international treaties on human rights ${ }^{1}$ for a very simple reason: the investment by a social and democratic state must necessarily begin with the idea of a constitutional democracy as a system deeply anchored in human rights. Human rights are - or, better yet, the effective respect for human rights - those rights that thus make up, currently, the primary principle of reference for evaluating the legitimacy of a legal-political system of law ${ }^{2}$.

Nevertheless, this special approach to human rights treaties is also justified because such treaties contain ethical and legal details. In fact, while treaties of the traditional type generally establish reciprocal obligations between states and are entered into for the benefit of the parties, treaties on human rights have the peculiarity that states adopt them even though such states may be neither the beneficiaries nor the intended subjects of these treaties, for the simple reason that such legal status is directed towards the protec-

1 This tendency seems to have begun with the Portuguese Constitution, in its wellknown Art. 16, which establishes that «Fundamental rights guaranteed by the Constitution do not exclude any other rights established in the applicable laws and rules of international law» and that «Constitutional and legal precepts pertaining to fundamental rights must be interpreted and integrated harmoniously with the Universal Declaration of Human Rights». In Latin America, the Peruvian Constitution of 1979 seems to present an innovation on the special treatment given to treaties on human rights, followed by the Constitutions of Guatemala in 1985 and Nicaragua in 1987. Modern constitutions of other countries, such as Brazil, Spain and Venezuela, show, to a greater or lesser degree, this tendency of modern social constitutionalism and, in particular, Ibero-American social constitutionalism, by recognising the status and special hierarchy given to treaties on human rights.

2 Thus, within the scope of modern social constitutionalism, the special and privileged treatment of human rights is justified based on a deep axiological and legalistic affinity between modern international law, which, beginning with the Charter of the United Nations and the Universal Declaration of Human Rights, places human rights at the pinnacle, and internal rights, which situate constitutional and fundamental rights in an equivalent manner: it is natural that modern constitutions underscore this affinity, by conferring a special status on the international instruments of human rights. 
tion of personal dignity: human rights treaties follow the establishment of public order common to the parties and are directed at states as the chosen beneficiaries, but rather, at individual persons; they are not treaties of the traditional type, entered into by virtue of a reciprocal exchange of rights for the mutual benefit of the contracting states, and their purpose is to protect the fundamental rights of all human beings, without consideration to their national origin, in terms of the individual's own state as well as the other states that are parties to the treaty.

In addition, upon approving these treaties on human rights, the states submit to a legal order within which they assume, for the common good, obligations not in relation to other states, but rather towards the individuals under their jurisdiction, whether nationals or foreigners. This point has been brought up repeatedly by the doctrine of law decided by the courts ${ }^{3}$ and has, at least, one transcendental legal consequence: the principle of reciprocity is not applied to human rights treaties in such a way that one state may not allege another's non-compliance with the human rights treaty for the purpose of excusing its own violations of these standards. This is so for the simple reason that such treaties have the particular feature that their rules make up guarantees benefiting individuals: obligations are imposed on the states, not for their mutual benefit, but rather to protect human dignity. Therefore, states may not invoke their internal sovereignty to justify human rights violations because they have made a commitment to respect them ${ }^{4}$.

The foregoing reasons for the special treatment of human rights treaties is further strengthened if we take into account, in addition, that respect for human rights in the international order established after World War II is considered an issue directly affecting and concerning the international community and that, therefore, it progressively establishes mechanisms for the protection of these rights. This special and privileged constitutional treatment to human rights treaties has, in turn, two very important regulatory

3 See, among other things, the Advisory Opinion of May 28, 1951 to the International Court of Justice on reservations to the Convention on the Prevention and Punishment of the Crime of Genocide and Judgment of July 7, 1989 by the European Court of Human Rights, in the case of Soering $v$ s. United Kingdom, nr. 14038/1988.

4 Art. 27 of the Convention of Vienna on the Law of Treaties establishes that no state signing any treaty can fail to perform it by invoking its internal law. According to Dulitzky apud Martin, Rodríguez, \& Guevara, 2004, p. 91, insofar as it concerns treaties on human rights, "the particular nature of agreements of this type justifies the special treatment which various constitutions [...] dispense to rights internationally protected by treaties. It is clear that the internal and international effect produced by ratification of a general international treaty is not the same as that produced by a treaty protecting human rights. This is one of the justifications by which the constituents are concerned with giving a special treatment to international conventions on human rights». 
consequences that also complement the justification of this constitutional approach.

On one hand, this approach allows us, in legal terms, to remove, at least in part, human rights treaties from the complex debate about the relationship between international law and internal law, to the extent that the constitution itself usually attributes a special power to international law on human rights (which become constitutional rights and fundamental rights when they are institutionalised) - it is not an accident that the expression «human rights» is generally used in its common sense meaning of "fundamental rights» and vice versa: it is evident that the degree of uncertainty with which expressions such as «human rights» and «fundamental rights» are used, including in the Universal Declaration of the Rights of Man $^{5}$ - without detriment to the level of priority that other treaties may have in the internal system of law. This means that a constitutional system of law can grant constitutional rank into international human rights laws, without that necessarily meaning that all treaties have such priority ${ }^{6}$.

On the other hand and directly related to the foregoing, this favourable internal treatment of human rights treaties allows for ongoing and dynamic feedback between constitutional and international law in the evolution of human. Hence, constitutions are, to a certain degree, linked almost automatically to international developments in human rights through the references to international human rights law made by the constitutional texts ${ }^{7}$.

In turn, and by taking into account that general principles of law recognised by civilised nations are one of the acknowledged sources of international law (as indicated in Art. 38.1 of the Statute of the International Court of Justice ${ }^{8}$ ), it thus becomes reasonable that international law take

5 See Martínez 1995; Marshall \& Bottomore, 1998; and Ferrajoli, 2005, p. 76 ff., for more considerations on the distinctions between «human» rights and «fundamental» rights.

6 Thus, the Argentine Constitution, after the constitutional reforms of 1994, establishes that, as a general rule, treaties do not have constitutional rank, although they have supra-legal rank; however, those same reforms confer constitutional rank on a specific label of human rights treaties and make it possible for other human rights treaties to gain access to that rank if Congress so decides by a qualified majority. Similarly, in the Brazilian case, after the constitutional reform of 2004, the possibility was established that international treaties and conventions on human rights could gain access to constitutional rank if they were so approved, in each chamber of Congress, after two rounds of voting by three-fifths of the votes of the respective members. In Colombia, the Constitutional Court has demanded that some treaties, as those on human rights, have a privileged constitutional treatment and comprise the block called the «block of constitutionality».

7 Cfr. Silva, 2002, p. $374 \mathrm{ff}$.

8 "The Court, whose function is to rule on the disputes submitted to it pursuant to international law, shall apply: a) international conventions, whether general or specific, which 
into account advances in constitutional law in terms of human rights for the development of international law itself, since the generalised constitutional adoption of certain human rights laws can be considered an expression of the establishment of a general principle of law.

So then, at least on the subject of human rights, a real «international constitutional law» or "law of human rights» ${ }^{9}$ has emerged from the dynamic convergence between constitutional law and international law, which mutually aid each other in the protection of human dignity. The development of human rights law is, therefore, energised by both international and constitutional law, the interpreter of which is forced to choose, by virtue of the principle of human advantages (pro homine), the standard most favourable to the dignity of persons - on the material level, we should not speak (or it is irrelevant to do so) about ranking the rules governing human rights, since the rule that most defines the status of a right, of a freedom or of a guarantee will always be applicable (in the specific case); speaking in material terms, therefore, it is not the status or ranked position of the rule that counts, but rather its content (because that which is most assured by law will always prevail).

The method of special and privileged constitutional treatment of human rights treaties enables national judges to apply, directly and with priority, those international standards (the international law) without having to necessarily engage in a debate as to whether the constitution favours the theory of monism, dualism or integration of the relationship between international and internal law (this does not mean that that debate does not have any relevance in this field of human rights, since it continues to be important; however, the privileged constitutional treatment by international rules of human rights greatly facilitates their application by national legal experts, who are no longer familiar with the dilemmas with which national judges may previously have faced). If the constitution is the applicable standard in which such treaties are integrated, it becomes clear that the legal thinker must apply international human rights regulations internally ${ }^{10}$.

«Human rights», an expression that belongs to the spheres of political philosophy and international law, encompass those guarantees, powers,

rules expressly establish rules recognised by the litigating states; b) international custom as proof of generally accepted practice with the force of law; c) general principles of law recognised by civilised nations; d) court decisions and doctrines published by the most prestigious scholars in the various nations as a supplementary means of determining the rules of law without prejudice to the provisions set forth in Article 59».

9 As Dulitzky apud Martin, Rodríguez, \& Guevara, 2004, p. 34, indicates, the expression law of human rights is drawn from Ayala Corao, while the expression international constitutional law has been simultaneously put forward by Flavia Piovesan.

10 Cfr. Graham \& Vega, 1996, p. 42 ff. 
freedoms, institutions or demands relative to primary or basic needs, which include all human beings by virtue of the simple fact of their human condition, for the guarantee of a life lived with dignity ${ }^{11}$; they are, then, independent of particular factors, such as personal status, sex, gender, ethnicity or nationality. From a more relational point of view, human rights have been defined as the conditions that allow an integrated relationship to be created between the individual and society allowing individuals to be persons, identifying with themselves and with others ${ }^{12}$.

To speak of human rights, then, is to speak of making rights accessible to groups of human beings who usually do not have access to them. In other words, an attempt is made to open up a new path, alternative and real in a true sense, leading to non-exclusive citizenship, democratic in the sense that it is participatory and oriented towards an authentically transformative praxis of society. Implementing this new path, of course, requires tremendous energy and tenacity and also the capacity to conceptualise content and techniques that permit re-education about social rights and their guarantees ${ }^{13}$.

It is well known that legal institutions can be instruments of social oppression if divorced from democracy, but also that, when coupled with participatory democracy and the strength of citizenship, the law can become a collective institution of freedom ${ }^{14}$. It is clearly not possible to have meaningful citizenship without democracy, nor is it possible to have a substantially democratic model of democracy without participatory citizenship. This being so, it is necessary to recreate certain premises in the field of law towards the body of law intended, not only as an instrument of social defence against

11 Cfr. Papacchini, 2005, p. 44. Similarly, see Nino, 1989, p. 40.

12 Cfr. De La Torre, 1996, p. 19. For Helio Gallardo and Joaquín Herrera Flores, human rights are supported on a social framework, by inter-subjective relations and experiences. According to Gallardo (2000), the foundation of human rights are transfers of power that occur between social groups, as well as the institutions in which they are articulated and the logic that inspires social relations. These transfers of power may or may not be effective and may be more or less precarious. For Flores (2000), along a similar line of thought, human rights are the practices and means by which spaces of emancipation are opened, which incorporate human beings into the processes of reproduction and maintenance of life.

13 In that sense, see Pereira \& Dias, 2008.

14 It does not seem to be difficult to perceive that, if the rules are created by the very parties interested in seeing them enforced, through the co-operation of social agents anchored in the autonomy-solidarity duality, then their materialisation is much more present in autonomy than in cases of anomia or heteronomy - it is necessary, then, to involve all participants in the production, interpretation and application of the rules, hence their legitimate legal exercise - and the legal model of action is, moreover, associated with a clearly democratic model of learning and self-awareness that takes into account the internalisation of values (cfr. Habermas, 2005, p. 129). 
abuses, but also as an instrument intended to safeguard citizenship itself in an inclusive context and permanent by creation of a more human, more just and more democratic model of development, by implementing concrete acts aimed at the full exercise of social rights, through all possible means and using available resources to the maximum extent.

\section{SOCIAL RIGHTS: THE NEED FOR (RE)CONSTRUCTION OF THEIR LEGAL FOUNDATION}

Economic, social, and cultural rights, most commonly called «social rights», an expression that belongs in particular to the fields of political and legal philosophy and international law ${ }^{15}$, often refer to matters related to basic expectations of human dignity, but rather, to the satisfaction of vital needs ${ }^{16}$ and, consequently, are stated as authentic fundamental human rights (when we speak about fundamental rights, we hold a functional understanding of the underlying character of rights, suggesting that to possess such a nature reflects the acquisition of a specific functional role in the ordering of a democratic state of law, in addition to assuming a substantial content of «human»

15 Social rights are associated with systems of social security, health, education, protection of the family, supply of food, etc., which are created and consolidated in Europe and in many Latin American countries between the last third of the 19th century and the second post-war period, within the context of the welfare state or social state (Esping-Andersen, 1998), and they are, according to Abramovich and Courtis (2006, p. 17), the "fruit of the attempt to translate into expectations (individual or collective), legally supporting the access to certain goods configured in consonance with the logic of this model». A common trait of the legal regulation of these spheres, then, would be the use of the power of the state for the purpose of balancing situations of material inequality, "whether based on an attempt to guarantee a minimum standard of living, better opportunities for deferred social groups, to compensate for differences of power in the relations between private parties, or to exclude a specific good from the free interaction of the market».

16 Thus, included among the social rights is the right to work (with the enjoyment of fair and satisfactory working conditions), along with other social rights to leisure, education, health, housing, security (including social security), protection of mothers and children, social assistance, etc. Social rights are recognised as fundamental in the International Covenant on Economic, Social and Cultural Rights (PIDESC), ratified by various countries, such as Spain (1977) and Brazil (1992), which provides in Art. 2 that each of the states who are parties to the PIDESC pledge to adopt measures, both individually and through international assistance and co-operation, in particular economic and technical, up to the maximum level of their available resources, in order to achieve progressively, and through all appropriate means (including and, in particular, the adoption of legislative measures), full exercise of social rights, a commitment that, in and of itself, is not contingent or limited by any other consideration. 
rights), essential for promoting human development and for freedom, democracy, justice and peace in the world, since they are expressed as rights that act as the premises on which to exercise other, equally fundamental rights related to freedom and autonomy of the individual.

Therefore, the discussion regarding the scope of guarantees of social rights often seems to be solely associated with persons in situations of greatest vulnerability within the social sphere - generally emphasis is placed on the fact that entitlement to social rights is a problem more related to the groups who cannot satisfy their basic needs, in other words, with the "most needy» - for whom the access to necessary resources to satisfy those basic needs tends to be residual, or even non-existent ${ }^{17}$. However, the truth is that social rights are of interest to everyone, given that they involve guiding principles in socio-economic policy within various geopolitical spheres (which, marked by the intensification of the globalisation process ${ }^{18}$, transcend local, regional, and even national limits), goods protected by social rights, involved in positional disputes, highlight material equality ${ }^{19}$ and are related to the existential, social and culturally outlined minimum, necessary not only for survival under conditions adequate with the dignity inherent to the individual as a human being, but also in order to guarantee the material conditions that allow for the true exercise of other rights, such as civil and political rights, related to the freedom and autonomy of individuals and necessary to promote participatory democracy and full citizenship ${ }^{20}$.

17 According to Pisarello (2007, p. 11), «this characterisation of social rights as rights which are most needed explains that their exercise and enshrining by law tend to recruit adherents among those who possess an egalitarian sensibility».

18 As we have already discussed, we are using the term globalisation in the meaning that Santos (2005) used to identify a multi-faceted, pluralistic, and contradictory phenomenon, with economic, social, political, cultural, religious and legal implications, interrelated in a complex way, which developed in the last decades of the 20 th century from a dramatic intensification of trans-national interactions that paradoxically, although they have been radically transformed, have intensified hierarchies and inequalities. The definition given to this term by Giddens (1990, p. 64, transl.) is also valid: «intensification of worldwide social relations that link distant localities in such a way that local happenings are shaped by events occurring many miles away and vice versa».

19 Cfr. Luis Prieto Sanchís apud Carbonell, Parcero, \& Vázquez, 2001, pp. 39-46.

20 According to Barcellos (2002, p. 198), as we have already pointed out, the existential minimum corresponds to the set of material situations essential for human existence with dignity: the existential minimum and the material core of human dignity reflect the same phenomenon. There exist, then, a tight linkage between social rights and satisfaction of basic needs of individuals, revealing an egalitarian sense in the behaviour of the state. Its purpose is equality through the satisfaction of basic needs, without which many people would be unable to achieve the level of human existence needed to enjoy individual, civil and political rights and to participate fully in political life. The PIDESC, in its preamble, recognises that, consistent with 
The progressive recognition of expectations related to social rights on the constitutional level and in international treaties - and their integration into the internal legal system of each country - impose obligations, both positive and negative, on public authorities and also, to a greater or lesser degree, to individuals ${ }^{21}$, concerning the satisfaction of such expectations and,

the Universal Declaration of Human Rights, the concept of the free human being, liberated from fear and misery, cannot be accomplished unless conditions are created that permit each person to enjoy his economic, social and cultural rights, as well as his civil and political rights. In this sense, according to Kliksberg (1997), access to the exercise of citizenship is a fundamental right, the first of the rights, because without it, there can be no access to any others. What is in play here is the right of people to inclusion in a highly complex and competitive society, which tends to exclude within a context in which human development has been severely undervalued.

21 Regarding the connection of private to fundamental rights, see Castro, 1988; Martínez, 1988; and Reis, 2005. In fact, private rights can assume responsibility for providing social rights, since social rights enjoy a «double face»: they are exercised with regard to public authorities as well as in relations between private parties. What lies behind these arguments is that social rights are not reduced to a simple obligation of the state, but rather also involve private parties. In effect, full respect of social rights becomes difficult without including private rights within the mandate of the law. It perhaps might be easier to explain it within the context of labour relations. Labour law regulates private activity between the employer and workers due to the real inequality that exists in said relationship. The state intervenes in that private relationship through regulation and reveals its role as guardian, which it plays in this context on behalf of the workers. This same process is repeated, in a similar manner with the other social rights. Thus, it seems admissible to say that the right to enjoy an adequate environment, or the right to the protection of health, or the right to strike and the freedom to organise into unions, should be considered as operational legal situations, both in terms of government and in legal relations between private parties. In an identical manner, Luño (1999, p. 93), upon studying German doctrine and jurisprudence on Drittwirkung der Grundrechte (exercise of fundamental rights towards third parties), holds: «In summary, what is involved is the application of fundamental rights, not only in relations between the state and its citizens, but also in the relations between private persons. Objections have been raised, in some doctrinal sectors, that this thesis is the fruit of an incorrect logical connection, unaware of the authentic nature of fundamental rights, since it understands that such rights are public subjective rights intended to regulate relations of subordination between the state and its subjects, but that it cannot be 'logically' projected into the sphere of private relations, presided over by the principal of co-ordination. From this perspective, fundamental rights are conceived as legal precepts that have arisen to protect citizens from the omnipotence of the state, but they do not have a reason to exist in relations between subjects of the same rank, where relations are developed between private persons. It is easy to notice the ideological nature of this reasoning, linked to a purely formal understanding of equality among various members comprising society. But it is a well-known fact that, in modern neo-capitalist society, formal equality does not presuppose material equality, and that the full enjoyment of fundamental rights in such a society is seen to be threatened, on many occasions, by the existence of centres of power in the private sphere, not less important than those belonging to public entities. From this vantage point, individuals have had to resort to a series of measures intended to overcome obstacles which, in fact, oppose the exercise of fundamental rights on the part of citizens as a whole in a context 
therefore, the effective promotion of human development. However, if social rights, from their foundation within the label of human rights, with their economic and cultural variations, have formed part of their legal heritage, they have also been the subject of strong criticism for their inclusion in this label, and conservative legal doctrine even now continues to debate whether social rights can be adapted within the legal framework of human and/or fundamental rights.

In a similar way, positive recognition itself of social rights has not proven to be useful for converting them into fully demandable expectations, nor into instruments truly suitable for satisfying the needs of the respective holders of these rights ${ }^{22}$. Furthermore, the gap between recognised rights and their effective exercise is too often cause for the words and discourse that proclaim them to be empty and without any practical effect.

In this context, despite the extraordinary expansion of institutional behaviour devoted to their development ${ }^{23}$, with the establishment of broad

of equality. Repercussions of the principle of Drittwirkung on the level of legal recognition of social rights have been clear [...]. Explicitly, and with special reference to social rights, the Federal Court of Labour has pointed out that these fundamental rights do not only guarantee freedom of the individual with respect to government, but also that they contain principles ordering social life, which also have immediate relevance for private-legal relations».

22 Historically speaking, reformist social states, within capitalism, as well as the so-called «real socialism» states, allegedly outside of it, attempted the "de-commodification» of the supply of certain basic resources, either in whole or in part, of their market value, in order to ensure the survival of people, as Esping-Andersen points out (1998, p. 35). But these experiences are seen, with certain frequency, to be contingent within their democratic scope and capacity for social inclusion by external and internal factors. In addition, the degree of satisfaction of social rights, above all in the most privileged regions, has been intimately related to asymmetrical relations of power existing between regions and central and peripheral countries: the widening of access of people at growing levels of consumption in central countries and regions, including in the form of rights, has been carried out, at least in part, at the expense of evident impoverishment and denial of basic rights to people in peripheral countries and regions.

${ }^{23}$ When we speak about development, it is important to stress that all development is social development, just as poverty is not an exclusively economic problem and economic growth is not development, since it is not enough to grow economically in order to promote social development. According to Franco (2002), development is a synergistic movement, which is confirmed in that class of social changes in which there are modifications in human and social factors guaranteeing the stability of social systems: in systems that are highly complex and removed from equilibrium, as human societies are, the development only occurs when internal patterns (among the components of the whole) and external patterns (with the surrounding environment) of interaction manage to install themselves, which better assure conditions of existence of the whole, in other words, of society itself. A society in which just a few individuals improve their living conditions, but in which the rest of the population - the majority - cannot manage to improve their general living conditions is not a society that is developed, even though it may be a society that is growing in economical terms. 
systems of compensation and inclusion throughout the last third of the 19 th century and, above all, in the first two thirds of the 20th century ${ }^{24}$ under the aegis of the so-called "welfare state» or «social state», the reality outlined from the neoliberal counterreformation movements of the 1970s, starting with the great crisis in the hegemonic model that had guaranteed the growth of the central capitalist countries during the post-war period (19451973), whose effects have extended until the current times and are revealed to be (to once again disguise themselves) more intense with each new crisis of capitalism, became common the point of view by which public authorities (and, therefore, the use of the state's power for the purpose of achieving equilibrium in material inequality or excluding certain goods from the free interaction of the markets) would be an inevitable source of undesirable bureaucratisation, and the rights related thereto, burdensome, real «traps», which would tend to trim economic effectiveness, personal liberties, and market freedoms, while they are not rights truly incompatible with those of freedom, or perhaps merely programmatic rights, imposing, despite their formal validity and the extension of social rights in many constitutions and international treaties, a new law of the ever more globalised market, which weakens the binding nature of the exercise of social rights and, with it, the true scope of the democratic principle and of social behaviour of the traditional state of law ${ }^{25}$.

Thus, contemporary discourse in regard to the legal, and not merely political, character of modern constitutions has not been extended to the scope of social rights. Insofar as concerns the latter, the capacity to which they can be exercised has remained relegated to a secondary level in relation to some or other rights, such as civil and political rights, above all if they are compared with proprietary rights such as property rights and the freedom of economic initiative. In a similar way, institutional guarantees of social rights - legislative and administrative - have been shown to be eroded

24 In the period spanning the two great world wars (1914-1918/1939-1945), and during the post-war period, the «social» states implemented many policies that sought to compensate for the excluding effects of asymmetrical growth, breaking down the political system of that time with the liberal paradigm of state absenteeism. The end of the First World War, above all, marked the start of an era of expansion of social rights, defined by the initiative of "constitutionalisation" of social rights observed in the Mexican (1917) and Weimar (1919) constitutions, and through the attempt of inter-nationalisation of those rights through the creation of the International Labour Organisation (ILO). The period that runs from the end of the Second World War until the decade of the seventies, on the other hand, reflects the period of greatest development of social rights. In that period, the great pillars on which such rights are structured were integrated into national constitutions and into the great international declarations of rights.

25 In this sense, see Pisarello, 2007. 
in the face of robust mechanisms for the protection of property rights and jurisdictional authorities have contributed little, in fact, to remove this tendency ${ }^{26}$. The insistent validity, among the more traditional legal agents, of the theory according to which social rights entail mere guiding principles or simple programmatic clauses, or the idea that jurisdictional entities neither can nor should do anything to guarantee them, as well as the recurrent idea of the reserve of the possible, are proof of this (new) lex mercatoria ${ }^{27}$.

In that way, the traditional democratic state, far from being converted into an authentic constitutional social state, has often operated in a residual way and as a simple legislative and administrative body, with contributions limited to complementing and correcting the actions of the markets and behaviour aimed at keeping the poor in their place and at ensuring, above all, public order and security in the service of those markets. With few exceptions, the "hard core» of social policies that have been adopted after the crisis, in the decade of the seventies, from the traditional Welfare State, is not related to the guarantee of social rights that lend themselves to generalisation, in other words, of stable expectations removed from the political context and, therefore, unavailable to the powers on duty: public policies have been patterned for selective intervention, related to the capacity with which certain segments can demand them and that, more than equalising what is unequal, tend to operate as effective discretional concessions and, therefore, revocable, when not serving as authentic measures for control of the poor ${ }^{28}$.

What we have been seeking to demonstrate throughout this paper is that, despite their appeal to technical discourse, this devalued perception of social rights rests, above all, on myths forged by ideological prejudices ${ }^{29}$. We are thus attempting to refute the primary myths conveyed in the political and legal mainstream that currently shape the perception of social rights and, by extension, public policies themselves. What we are defending, in synthesis, is that the current idea according to which social rights are «second generation» rights - or even «second dimension» rights, in other words, «second-hand»

26 Cfr. Martín, 2006, p. 11.

27 In reference to the legal effectiveness of the social state and social rights, Ibánez (1996, p. 35) affirms that, by the 1990s already, «social character, with a much thicker brushstroke, had already been transformed into social principle, and social principle, in turn, was transformed into more than a few rules to be exercised on their own".

28 Vuolo (2004, p. 14), when analysing the policies of the war against poverty in Argentina and other regions in Latin America, affirm: "current policies 'against' poverty are as poor as the intended beneficiaries of such policies. In reality, they are policies 'of' poverty, whose purpose is to administer and manage the poor, while keeping them in a socially static position so that they do not upset the operation of the rest of society».

29 In this sense, see Pisarello, 2003 and 2007. 
rights, while property rights would be first generation, first dimension, or "first-hand" rights - is raised as a simple ideological option, and that we cannot speak about the enforcement of other rights, including civil and political rights themselves, related to the freedom and autonomy of individuals (truly essential for a democracy and full citizenship), without the guarantee of the existential minimum, a panoply of economic, social and cultural goods that reflect what is usually denominated as «social rights». We are seeking to demonstrate in this context that we cannot guarantee social rights from the assumption of the prior and necessary accomplishing of exclusively civil (individual) and political rights, nor even, on the contrary: in synthesis, the concept of the free human being, liberated from fear and misery, cannot be accomplished unless conditions are created allowing each person to enjoy his economic, social and cultural rights as well as his civil and political ones.

\section{CONVERGENCE AND COMPLEMENTARITY OF FUNDAMENTAL HUMAN RIGHTS IN INTERNATIONAL LAW}

Rights identified as «social» usually, and within the context of the history of both law and legal sociology, appear as rights belonging to the generation that is later than that of civil and political rights. Social rights, according to this perspective, come after such civil and political rights, which is assumed to confirm, in more functionalist terms, that the problem of satisfying social rights should be solved historically only after civil and political rights have been satisfied, which would include, obviously - if not primarily - proprietary rights.

Apart from their wide dissemination, even for instructional purposes, this traditional perception of social rights as rights of late onset is based on preconceptions that are tendentiously restrictive and deterministic and that justify, in theory, a devalued protection of social rights.

It is true that the modern history of social rights had its beginnings in the great social revolutions of the 19th century. Nevertheless, together with that «history» properly speaking, it is possible to verify the existence of a rich «prehistory» marked by various institutional policies directed at resolving situations of poverty and social exclusion that predated the actual emergence of the modern European state and that, in a definite way, are similar to modern demands in terms of social rights ${ }^{30}$.

Thus, we can say that the expectations that correspond to what are usually called «social rights» always existed, just as mechanisms and pro-

30 In this sense, see Pisarello, 2007. 
grammes intended for intervention within the social sphere have always existed. In this way, different institutional mechanisms existed in medieval and ancient times, whether or not they belonged to the state, and were clearly directed at fulfilling the needs of individuals in conditions of greater vulnerability within the social setting ${ }^{31}$. At times, these measures had, in and of themselves, an egalitarian sense ${ }^{32}$; other times, the purpose of these mechanisms was to resolve issues of exclusion in a blatantly authoritarian way by controlling the more vulnerable segments and forcing individuals to (re)enter exploitative labour relationships ${ }^{33}$.

Over the course of existence of modern states, that contention between conservative and preventive policies and egalitarian policies recurs. Frequently, the mechanisms aimed at providing relief of the poor and job centres were cut from the same cloth as that of policies of public order intended to control the conditions for perpetuation of productive structures.

In many cases, aid to individuals in conditions of greater vulnerability within the social sphere, initially discretional, prompted tangible benefits that reflected claimable rights ${ }^{34}$ : during more egalitarian episodes of modern revolutions, the claim of rights to assistance and access to scarce or centralised resources, such as land and food, was stated as a recurring demand of the popular sectors, almost always accompanied by a request for the extension of the rights of participation ${ }^{35}$.

Thus, for example, in England, the claim for rights of participation and access to land and social assistance was a common element in the charters motivated by the levellers and diggers over the course of the seventeenth

31 Cfr. Ritter, 1999, p. 33.

32 In this sense, for instance, the assistance that guaranteed access to the public baths in the Athenian polis and the agrarian laws of Republican Rome, which ensure access to land or to a minimum quantity of food. In pre-Colombian America, we find in the Incan empire one of the first manifestations of a system of social security, understood as a rational system of conjugation of collective effort in order to provide a type of social security: the property system in existence at that time provided for the cultivation, through common labour, of certain lands, whose product was directed at meeting the nutritional needs of the elderly, the ill or the disabled and orphans, all of whom lacked the ability to be productive on their own (Oliveira, 1989, p. 181).

33 That was the sense, for instance, of laws on poverty, which, during incipient capitalism, tended to replace the ancient idea of charity or beneficence by that of re-education for work. As Castel points out (1995, p. 47), in countries of both Catholic and Protestant tradition, the distinction was introduced, also in legal terms, between the deserving poor, willing to work in exchange for assistance given, and the undeserving poor, devoted to vice and idleness, and, therefore, dangerous to society.

34 Dean (1997, p. 3) characterises this process as juridification of well-being.

35 In this sense, see Abramovich \& Courtis, 2002 and 2006; Pisarello, 2003 and 2007. 
century ${ }^{36}$. On the one hand, distribution of land, assistance to the more vulnerable segments and the establishment of mechanisms of participation in the colonies of North America were present in different charters, some of which included anticipation of advanced experiments in agrarian democracy ${ }^{37}$. Thus, the Declaration of Independence, although it did not resolve problems automatically such as slavery, addressed and recognised certain rights to be self-evident truths, such as the right to life and the pursuit of happiness, clearly related to the hopes that today are connected to «social rights", although it attempted to exclude rights of ownership that were elevated to the constitutional rank only in the Constitution of Philadelphia $(1787)^{38}$.

In France, the issue pertaining to the extension of social rights and rights of participation always occupied a central place throughout the course of the revolution. Thus, the Constitution of 1791, although monarchic, included issues pertaining to the right to assistance to the poor and public education; on the other hand, in 1793, with the advent of the Jacobin Democratic Constitution, recognition of social rights for citizens called into question the inviolable nature of private property, and was linked to a expansion of participation rights ${ }^{39}$. The declaration of rights contained in the preamble of the Constitution granted, together with equality of citizens' rights, that of contributing to the law-making process and the right to the appointment of legal representatives (Art. 29) ${ }^{40}$, the obligation of the state to institute public aid needed for the subsistence of the more vulnerable citizens (Art. 21) ${ }^{41}$ and

36 About these popular revolts, Thompson (apud Fontana, 1982, p. 81) emphasises that what was at stake, in reality, was not the civil right to property, but alternative definitions of the right to property, such that claims made by the popular classes clearly became social issues.

37 For example, Art. 79 of Body of Liberties de Massachusetts, written in 1641 by the Reverend Nathaniel Ward, established that if a man, upon his death, did not leave his wife a pension sufficient to sustain her, she would be relieved afterward, upon submitting a complaint to the General Court: «If any man at his death shall not leave his wife a competent portion of his estate, upon just complaint made to the General Court she shall be relieved».

38 In this sense, see Austin Beard, 2004.

39 According to Pisarello (2007, p. 22), «the expression 'social rights' appeared in a draft submitted to the Convention of 1783 by the agronomist Gilbert Romme [...]. In its session on April 24, 1783, Robespierre, for his part, proposed to the Convention, in the name of 'fraternity', the need to moderate great fortunes through a progressive tax and to 'make poverty honourable', by guaranteeing everyone the right to freedom and existence».

40 "Chaque citoyen a un droit égal de concourir à la formation de la loi et à la nomination de ses mandataires ou de ses agents» ("Each citizen has an equal right to contribute to the creation of the law and to the appointment of its representatives or agents»).

${ }_{41}$ "Les secours publics sont une dette sacrée. La société doit la subsistance aux citoyens malheureux, soit en leur procurant du travail, soit en assurant les moyens d'exister à ceux qui sont hors d'état de travailler» ("Public assistance is a sacred debt. Society owes subsistence to its wretched 
the right to gain access to public education for all (Art. 22) ${ }^{42}$. All these rights were protected by mechanisms of social guarantees relying upon the actions of all, to guarantee each person's enjoyment of his rights (Art. 23) ${ }^{43}$ and on the rights and obligations to revolt in the event that such rights were violated by the government (Art. 35) ${ }^{44}$.

The revolutionary cycle begun in 1848 was, perhaps, the greatest turning point in the history of the demand for social rights, since an element appeared at that time that neither the most formalistic reading on generations of rights would be able to underestimate: the existing structural contradiction between the generalisation of civil, political and social rights and the recurring maintenance of the tendentiously absolute nature of private property and contractual freedoms ${ }^{45}$. In fact, the Constitution of November, after the revolt of 1848 , kept alive the "social issue» in its preamble by establishing the duty of the Second Republic to ensure needy citizens of subsistence, by providing them with work suited to their capabilities or by granting them assistance in the case of those unfit for work ${ }^{46}$. Despite its limitations,

and miserable citizens, whether finding work or providing them with the means of existence for those who are unable to work»).

42 "Linstruction est le besoin de tous. La société doit favoriser de tout son pouvoir les progrès de la raison publique, et mettre l'instruction à la portée de tous les citoyens» ("Everyone needs an education. Society must promote public education with all its power and put education within the reach of all citizens»).

43 «La garantie sociale consiste dans l'action de tous, pour assurer à chacun la jouissance et la conservation de ses droits; cette garantie repose sur la souveraineté nationale» ("Social guarantee consists of action by all, in order to ensure each individual of the enjoyment and preservation of his rights; this guarantee rests on the national sovereignty»).

44 "Quand le gouvernement viole les droits du peuple, l'insurrection est, pour le peuple et pour chaque portion du peuple, le plus sacré des droits et le plus indispensable des devoirs» ("When government violates the rights of the people, insurrection is, for the people and for each segment of the people, their most sacred right and most essential duty»).

${ }_{45}$ In this sense, Tocqueville (1994, pp. 34-35) states about the period that «the French Revolution, which abolished privileges and destroyed all exclusive rights, has allowed one such right to subsist and in an ubiquitous way: that of property [...]. Today, that the right of property does not appear but as the last relic of an aristocratic world which has been destroyed [...] a political struggle will ensue between those who have and those who have not. The great battlefield will be property and the primary issues of policy will turn on modifications, more or less profound, which will have to be introduced into property law».

46 "La République doit protéger le citoyen dans sa personne, sa famille, sa religion, sa propriété, son travail, et mettre à la portée de chacun l'instruction indispensable à tous les hommes; elle doit, par une assistance fraternelle, assurer l'existence des citoyens nécessiteux, soit en leur procurant du travail dans les limites de ses ressources, soit en donnant, à défaut de la famille, des secours à ceux qui sont hors d'état de travailler. - En vue de l'accomplissement de tous ces devoirs, et pour la garantie de tous ces droits, l'Assemblée nationale, fidèle aux traditions des grandes Assemblées qui ont inauguré la Révolution française, décrète, ainsi qu'il suit, la Constitution de la République» ("The 
the events of 1848 and the brief experience of the Commune of Paris later in $1871{ }^{47}$ played an essential role in the subsequent developments in social rights ${ }^{48}$.

After an intense cycle of social conflict that extended from the last third of the 19th century until the mid-20th century, states and their legal decisions experienced, with more or less intensity, an open process of «socialisation" that affected different branches of law ${ }^{49}$. Labour law emerged, then, by virtue of the enormous social problems originating in the Industrial Revolution, by stimulating a growing intervention by the state in the labour market for protectionist purposes, which tended to inhibit abuses of capital and to make the material expansion of social rights viable, by institutionalising rights unthinkable until then, such as unionism, strikes and collective bargaining ${ }^{50}$. However, if the notion of social rights was deeply derivative of the labour law, it also was confirmed that this notion should not be used solely as the basis of the labour Law, but also for all those legal expressions of a model organised around the basis of collective action, the search for parity and their linkage to social relations in which groups are identified as disadvantaged. Civil law went on to allow criteria of objective responsibility, by abandoning the idea of guilt, for damages caused by private parties who enjoyed a special position of power within the context of commercial relations or consumption. Finally, the penal code moderated its deeply repressive function, by incorporating criteria of re-socialisation.

This tendency was established with the Keynesian pacts in the post-war period and with a relative consolidation of different spheres of the welfare

Republic must protect citizens themselves, their family, their religion, their property, their work, and make education, needed by everyone, available to all: it must, through fraternal assistance, ensure the existence of its neediest citizens, whether by finding them work, within the limits of its resources, or by providing, in the absence of family, assistance to those who are unable to work. - In view of the accomplishments of all these duties, and in order to guarantee all those rights, the National Assembly, faithful to the traditions of the great Assemblies that inaugurated the French Revolution, does hereby declare, as naturally follows from the foregoing, the Constitution of the Republic»): Preamble to the French Constitution of 1948, Paragraph VIII.

47 On the milestones of the Commune of Paris, see Marx, 1972.

48 In this sense, see Abramovich \& Courtis, 2002 and 2006; Pisarello, 2003 and 2007.

49 The idea about socialisation of law and, consequently, of traditional civil and political rights themselves, was upheld between the 19th and 20th centuries by various authors, such as the German Ferdinand Lasalle, the French Léon Duguit and George Gurvitch, and the Austrian Anton Menger.

50 López (2002) raises the idea about the formation of the right to work as a right that has been won and granted at the same time: concession and victory, then, would constitute the double face of modern labour law. But we will expand on this idea in greater detail below. 
state created in prior decades. Civil and political rights were extended to sectors excluded until then from their influence, and specific rights were recognised in economic, social and cultural fields that safeguarded hopes and expectations relating, for example, to issues concerning work, education, health and housing ${ }^{51}$.

In these contexts, it is clear that, if we can conceive the idea that social rights reflect rights that have been won - especially by the working class - we should recall that the expansion of social rights corresponds, concomitantly, to the objective needs of the capitalist system, by permitting the reproduction and qualification of the labour force and, at the same time, by extending the possibilities of consumption ${ }^{52}$. States in the post-war period did not truly reveal themselves as protectionist or democratic, or they did so in a sufficiently attenuated manner. Nevertheless, conditions in the regulation of the labour market improved, as did the access to consumer markets and to basic services for an important segment of society, although states may have permitted the proliferation of foci of arbitrariness by letting themselves be colonised by the bureaucratic and commercial powers and especially by using the practice of concentrated decisions that excluded or stigmatised groups that were more vulnerable ${ }^{53}$.

In this way, although the "modern" history of social rights has its beginnings in the great social revolutions of the 19th century, which, from a formal point of view, social rights acquired only a constitutional status in the period in the 20th century after the Second World War - without prejudice, however, to the experiences of the "constitutionalisation" of social rights in the historic constitutions of Mexico of 1917 and of the Weimar Republic of 1919 -, we point out that it is possible to redeem a more complex history that leads to conclusions different from those usually extracted from the tra-

51 For an historical and institutional categorisation of those different models, see EspingAndersen, 1998, p. 9 ff.

52 As history shows, the abolition of slavery and the overcoming of the model of forced servitude, of feudal inspiration, were crucial - and reflected, therefore, real premises - for the development of capitalism: capital was only able to develop itself as a system of obtaining surplus value in the form of buying and selling between equals, through the use of a free labour force in one of the classic tales of the episodes of 1917, Serge (1993) indicates the year 1861 as the initial milestone of the processes that would involve Russia in the whirlwind of transformations of modern capitalist society, the year in which the Czar Alexander II decreed the abolition of serfdom of the peasants, by formally abolishing feudalism in the Russian Empire. It was not an accident that the War of Secession of the United States started during the same period, motivated, among other things, by the problem of the freedom of the labour force from the bonds of slavery (cfr. Delfino, 2007, p. 20).

53 For a critique of the «social» state from a protectionist and democratic perspective, see Habermas, 1986. 
ditional literature. Here, we can emphasise situations in which the expansion of social rights was vindicated simultaneously with the expansion of civil and political rights and the restriction on proprietary rights and contractual freedoms ${ }^{54}$.

In summary, the idea of reducing social rights to rights of recent recognition, always secondary to more traditional and more standard fundamental, civil, and political rights minimises the breadth and complexity of the history of those same rights. Such a history, nevertheless, helps us to understand the profound differences existing between social policies, more or less discretional and implanted according to the economic, cultural and political events of the time, and the demand for social rights, which are more or less stable over time and, therefore, essential to the existing powers. Such an understanding allows us, then, to evaluate certain policies as conservative and preventive, related to a limited recognition of social rights on the one hand, and, on the other, as other substantially egalitarian and democratic policies, linked to the simultaneous satisfaction of civil, political and social rights.

In addition, expanding on the theory that hosts a linear trajectory of "generations» of rights allows us to perceive the multiplicity of ways, scales and aspects related in a substantial way to the claim of social rights, by emphasising the truly simultaneous, convergent and complementary nature of the claim for civil, political and social rights. Thus, all distinctions disappear between institutional and extra-institutional means for claiming human rights and between local, regional, national and international scales, as well as distinctions between individuals and citizens as intended beneficiaries of social rights.

In those contexts, social rights can only be considered as essential in order for us to give material content to individual and political rights connected with freedom and the autonomy of individuals and citizens, which paradoxically and simultaneously are also shown to be essential to ensuring social rights.

All human rights are indivisible and interdependent. Violations of social rights, in this context, are often related to violations of civil and political rights in the form of repeated denials. In the same way that it is necessary to co-ordinate efforts in favour of the right to education in order to fully enjoy the right of freedom of expression, it is necessary to take measures directed at reducing infant mortality, hunger, epidemics and malnutrition, in order to enjoy the right to life.

\footnotetext{
54 In this sense, see Pisarello, 2003 and 2007.
} 


\section{INTERDEPENDENCE AND INDIVISIBILITY OF FUNDAMENTAL HUMAN RIGHTS IN INTERNATIONAL LAW}

When, from the perspective of history, which offers us the theory that hosts the trajectory of generations of rights, we move to the legal perception of the grounds on which social rights rest, we are usually presented with an image of such rights relegating them to a subordinate position in relation to traditional civil and political rights ${ }^{55}$, axiologically speaking.

That perspective allows for different approaches. The first, fairly current, is the approach that maintains that civil and political rights are very closely related to interests that are, in fact, fundamental to everyone, including life, liberty, privacy, and by that (or with that), dignity itself, whereas social rights are not. On the other hand, the idea that civil and political rights are restricted to values and principles such as freedom and security, whereas social rights are restricted to the promotion of equality, is an approach that is sufficiently well-disseminated. So, as a consequence, by accepting such propositions, we are forced to choose: either we are concerned about promoting civil and political rights, relegating the idea of promotion of equality to a secondary level, or we are concerned with promoting social rights, relegating the guarantee of personal liberties to a secondary level.

This involves, however, a truly contradictory perspective, one that is based on ideological premises that include, in fact, obvious discursive inconsistencies. In a certain way, the axiological grounds of all rights leads to the idea of equality ${ }^{56}$. What converts a right grounded in valorative terms and allows such categorisation, is its egalitarian structure, that is, the fact that it refers to interests, which have the tendency to be generalised or inclusive, and accordingly, are truly inviolable and inalienable ${ }^{57}$. Nevertheless, the principle of equality is a relational principle ${ }^{58}$, and questions about subjects and the object of equality have admitted different answers.

As to the subjects involved, the truth is that, in modern states, an extensive number of rights, civil, political and social, have been linked to the category of citizenship, which has emerged as a clearly inclusive idea, and was converted, especially in a society such as the current one, characterised by

55 Cfr. Añón \& Añón, 2003, p. 115 ff.

56 On equality as a fundamental principle in the discourse on rights, see Dworkin, 2005.

57 This would be precisely what would distinguish a fundamental right from a privilege, whose structure is, by definition, tendentiously selective, exclusive, and alienable, as Ferrajoli stresses (1990 and 2006).

58 According to Pisarello (2007, p. 38), «the principle of equality is a relational principle, whose terms of comparison must be defined: equality, yes, but between whom? And for what?». 
migrations and massive internal and external relocations, into an authentic exclusive and excluding status of privilege: when we speak of human rights, international law, at least in a tendentious manner, seeks to attribute them to persons generally, and not only to citizens, thus introducing a key idea on which to expand egalitarian understanding of the subject of rights. As to the object of equality, confronted by the theory reducing the categorisation of rights to an excluding axiological foundation, we can easily verify that, in reality, all rights - civil, political and social - are based on the notion of equal satisfaction of certain needs held to be basic for all people, as well as their equality, dignity, freedom and security ${ }^{59}$.

Another debatable approach refers to social rights as rights - as opposed to others, such as civil and political - intrinsically related to equality, and not to dignity. In essence, the principle of dignity is consubstantial with the individual's right to object to the imposition of oppressive or humiliating conditions of life - according to the Jacobean Constitution of 1973, resistance to oppression is a consequence of all the other rights of man: "La résistance à l'oppression est la conséquence des autres Droits de l'homme» («Resistance of oppression is the consequence of the other rights of man») -, and constitutes a central element in the modern justification for human rights, and their recognition is assumed, in fact, in any democratic debate on rights held to be fundamental, including those discussions concerning their correct categorisation as such. Thus, in normative terms, the specification of what we could consider a «dignified life» or «undignified life» is related to negative and positive elements ${ }^{60}$. From a utilitarian perspective, for example, the idea of dig-

59 In this sense, see Carter, 2005, and, in particular, Balibar, 1992.

60 The principle of dignity of the person is inscribed in ethical and political traditions different from traditional liberal thought on socialist ideology. In positive terms, it is recognised by Art. 10.2 of the Universal Declaration of the Rights of Man (1948) and in different constitutions, of which the following constitutions, in addition to the Brazilian of 1988, are examples: the German Constitution of 1949 (Art. 1: «1. Die Würde des Menschen ist unantastbar. Sie zu achten und zu schützen ist Verpflichtung aller staatlichen Gewalt. 2. Das Deutsche Volk bekennt sich darum zu unverletzlichen und unveräußerlichen Menschenrechten als Grundlage jeder menschlichen Gemeinschaft, des Friedens und der Gerechtigkeit in der Welt». - «1. The dignity of man is untouchable. All public authority has the duty to respect and protect it. 2. With this, the German people declare the rights of human beings to be inviolate and inalienable, as the foundation of all human communities, peace, people and justice in the world»); the Spanish Constitution of 1978 (Art. 10: «1.1 The dignity of the individual, the inviolate rights inherent to him, his free personal development, respect for the law, and the rights of others, are the foundation of public order and social peace»); and the Colombian Constitution of 1991 (Art. 1: «Colombia is a social state of law [...] founded on the respect for human dignity, work and solidarity between the persons comprising it and in the general interests [of society]»). On the scope of the principle of dignity in modern constitutional thought, see Gutiérrez, 2005, and, in particular, Sarlett, 2002, p. $29 \mathrm{ff}$. 
nity - or of a dignified life - is better related to a set of conditions that allow the physical and psychic integrity of the individual to be maintained, and, in consequence, seeks to minimise situations of unease, injury or oppression; from another constructivist perspective, the idea of dignity is more tightly related to autonomy and free development of personal identity ${ }^{61}$, something closer to what we would call «human development».

In reality, these perspectives are not reciprocally exclusive or contradictory. If the action of avoiding situations of unease, injury or oppression can have, in legal terms, relevant value, which is justified, among other reasons, because those actions are true premises on which to seek the free development of status and, as a result, participation in public affairs. A greater or lesser degree of assurance of equal dignity depends, therefore, not only on the preservation of physical and psychical integrity, but also on the very possibilities of exercising these personal freedoms and, for that reason, the democratic nature of a given society.

From the characterisation of social rights as rights effectively related to the equal dignity of persons, approaches according to which civil and political rights, as rights related to liberty, stand in opposition to social rights, also lack coherence. The distinction between rights of equality and rights of liberty prevailed, in fact, during the so-called "Cold War", when the international community reached the point of recognising them in separate covenants, both in 1966; the International Covenant on Economic, Social and Cultural Rights (PIDESC) and the International Covenant on Civil and Political Rights (PIDCP) ${ }^{62}$. Ratification of one or the other even reached the point of being considered, for states at the time, an ideological matter: either civil and political rights were chosen, along with liberty, or economic and social rights were chosen, along with equality ${ }^{63}$. After the cold War, with the fall of the European Communist bloc led by the Soviet Union, objective conditions for adopting the theory that would eventually be claimed by the Declaration of Human Rights of Vienna (1993), that of the indivisibility and interdependency of all rights, arose.

Finally, one last apparent tension between equality and diversity should be pointed out when we refer to the philosophical and normative percep-

${ }^{61}$ From that perspective, therefore, the principle of dignity is more closely related, in reality, to the satisfaction of interests required for each person to freely pursue his objectives and life plans and participate in the construction of a social life (Fabre, 2000, pp. 12-13).

62 The PIDESC was adopted by the Organisation of the United Nations (U.N.) in 1966 and it contains, together with the International Covenant on Civil and Political Rights (PIDCP), the primary commitments arising from the Universal Declaration of Human Rights.

63 On the origin and discussions involving ratification of covenants, see Craven, 1995. 
tion of social rights: the theory according to which social rights stand guard over a type of social homogeneity, to the detriment of pluralism and cultural diversity. If we accept the fact that all human beings are intrinsically related through equality, dignity and freedom, we can easily conclude that, as instruments enabling individuals to participate in social life and choose their own life plans, social rights, as the very notion of liberty, carries within itself the kernel of pluralism and cultural diversity ${ }^{64}$. That being the case, civil, political and social rights are based on the need to satisfy the broadest right to equal liberty and equal diversity of all people.

To summarise, the idea of axiological subordination of social rights to civil and political rights cannot be sustained ${ }^{65}$. On the contrary, all those rights - civil, political and social - can be considered indivisible and interdependent, heirs to a common foundation: equality in dignity, liberty and diversity of all people.

\section{HOW FUNDAMENTAL HUMAN RIGHTS CAN BE DETERMINED AND PROTECTED IN INTERNATIONAL LAW}

Included among those who, having abandoned the technical drawing of the generations of rights, are inclined to recognise that social rights are not simply rights of late onset, which come after the so-called fundamental, civil, and political rights and that, despite the usual philosophical and normative perception of the foundation of social rights, manage to conceive of civil, political and social rights as rights with a common foundation, there are those individuals who are convinced that social rights can be structurally distinguished from civil and political rights, possessing a structural difference that influences, first and foremost, notions about how it may be possible to safeguard social rights.

In this context, civil and political rights are traditionally identified as negative, non-onerous rights that are claimable and, in addition, easily protected, while social rights would be positive rights that impose a burden, are indefinite and exercised in an indirect way; they are dependent, in their specificity, upon criteria of reasonability or availability, with reserve of the possible, in other words, dependent on contingencies that are, above all, economic within a clear context of positional struggles.

${ }^{64}$ About the link between capability and freedom and between capability and diversity, see, for instance, Sen, 2006, pp. 9 and 86.

65 In this sense, see Pisarello, 2003 and 2007. 
In synthesis, social rights serve, in and of themselves, as mere guiding principles or programmatic clauses, and, given their collective dimension, certain forms intended to safeguard social rights before jurisdictional entities would not be possible, which, in view of the reserve of the possible, could do nothing to guarantee them ${ }^{66}$.

he allegation that civil and political rights traditionally generate negative obligations, of abstention, and for this reason, they are inexpensive ("cheap») rights, easily safeguarded, as opposed to social rights seen as positive, requiring intervention, which would then be "costly" rights, difficult to safeguard, and unsustainable, since neither civil and political rights can be characterised solely as negative rights of abstention, nor can social rights be characterised solely as positive rights requiring intervention.

Civil and political rights are also positive rights with social benefits. Therefore, the right of property, for example, does not demand, as traditional liberal thought usually points out, only the absence of arbitrary interference, but rather a wide number of public benefits imposing burdens, which extend from the creation and maintenance of registries of various types (automobile, real estate, or industrial property, for example) to the creation and maintenance of security forces and jurisdictional entities that can guarantee compliance of contracts involving property.

In a similar manner, the political right to vote contains a broad and burdensome infrastructure that includes minimal issues, such as ballot boxes, paper ballots, etc., to others that are more complex, such as polling clerks, counting devices, recounts and registries, logistics, jurisdictional entities, etc. All civil and political rights, in summary, entail in a similar manner to social rights, a distributive dimension, the satisfaction of which requires multiple resources, both financial and human. In sum, it is not only social rights that imply costs for the state; civil and political rights, insofar as they require the abstention of the state and/or of the individual; that is to say, non-intervention in the spheres of autonomy and freedom of individuals depend on a burdensome state structure in order to become a reality ${ }^{67}$. What is usually at stake, therefore, is not how to guarantee "costly» rights, but rather to decide how and with what kind of priority those resources will be assigned, which all rights - civil, political and social - require in order to be satisfied.

Likewise, social rights, although usually associated with social benefits (positive rights) also entail duties of abstention. Thus, the right to housing requires respect, not only for the demand of policies that allow access to

66 On different variations of that approach, see Abramovich \& Courtis, 2002, p. $21 \mathrm{ff}$.

${ }_{67}$ The idea that all rights have a cost makes up the central argument of Holmes $\&$ Sunstein, 1999. 
housing, but also the right not be arbitrarily evicted and not to include abusive clauses in rental agreements or real estate purchase contracts. The right to work is fundamentally related to the protection against arbitrary dismissals, which involves a duty of abstention on the part of companies.

We can affirm, in short, that all rights, whether they are civil, political or social, establish, in one way or another, claimable negative obligations of abstention or respect, as well as positive obligations that require intervention or satisfaction from the public authorities, and, in addition, obligations concerning their protection against violations arising from acts or omissions by private individuals ${ }^{68}$.

On the other hand, one of the primary obligations that social rights generate for the public authority involves respect towards a negative duty, grounded in the principle of non-regression, which, according to the Committee on Economic, Social and Cultural Rights of the organisation of the United Nations ${ }^{69}$, obligates public authorities to not adopt policies and, consequently, to not allow rules that would erode, without justification, the status of social rights in the country.

That same principle of irreversibility of social achievements has been articulated in constitutional terms since the approval in Germany of the Fundamental Law of Bonn (1949) ${ }^{70}$ as a corollary of the constitution with normative power and of the minimum or essential content of rights recognised therein, and it was extended to various other legal systems, such as the Portuguese ${ }^{71}$, the Spanish ${ }^{72}$, the Colombian ${ }^{73}$, the Brazilian ${ }^{74}$ and the French ${ }^{75}$.

68 Shue, 1980, pp. 52-53, distinguishes between the wide spectrum of attendant obligations of all civil, political and social rights for public authorities, concentrating, above all, on three: to avoid deprivation, to protect, and to aid.

69 The Committee on Economic, Social and Cultural Rights of the organisation of the United Nations is the entity charged with supervising compliance with the PIDESC (1966). According to the Committee, "any deliberatively regressive measure [...] would require the most careful consideration and should be fully justified in reference to the totality of rights provided under the Covenant and within the context of full exploitation of the maximum resources available» (cfr. Courtis, 2006, p. 79).

70 On the German case, see Franco apud Courtis, 2006, p. $361 \mathrm{ff}$.

71 In Portugal, Canotilho (1999, p. 449) points to the existence of implicit constitutional clauses that prohibit a «reactionary evolution» or «social regression».

72 In Spain, the subject of the irreversibility of social rights was discussed by Marín, 1996, p. $91 \mathrm{ff}$.

73 Cfr. Arango apud Courtis, 2006, p. $153 \mathrm{ff}$.

74 Cfr. Sarlett apud Courtis, 2006, p. $329 \mathrm{ff}$.

75 According to Roman (2002, p. 280), the French Constitutional Council has made use, although irregularly, of the so-called cliquet anti-retour (reverse-lock ratchet). 
The idea of non-regression does not remove from the state the possibility of promoting certain reforms within the context of its social policies, which are prima facie regressive (i.e., regressive at first sight), for instance, by (re)assigning the resources needed for the social inclusion of certain groups who are in conditions of greater vulnerability. Indeed, public authorities always have to demonstrate to the citizens that the changes that they are seeking to promote will be beneficial, in the final analysis, to the greater protection of social rights.

The duty of non-regression on the subject of social rights is related to the duty of progressiveness ${ }^{76}$. This principle authorises public authorities to adopt programmes and policies intended to develop social rights in a gradual way, to the extent that there exist available resources (the reserve of the possible), but does not allow states to defer indefinitely the satisfaction of rights established as a standard - budgetary scarcity, in and of itself, cannot be raised as a sufficiently solid argument for withdrawal of the imperative for implementing fundamental social rights; although public resources are limited, the state should assign specific budgetary resources to satisfy social rights to the extent possible, but always exerting maximum effort to promote the guarantee of such social rights. On the contrary, it requires specific actions, beginning with the act of demonstrating that the maximum effort is being made and that the maximum resources available are being used (human, financial, technological, etc.) in order to satisfy, at least, the essential content of social rights and to find solutions, on a priority basis, for groups in situations of greater vulnerability.

In summary, if the idea of the reserve of the possible can be used as an argument for citizenship by governments in a context of positional struggles, in the sense of justifying the lack of materialisation of given social rights, if all rights - whether civil, political or social - are, to a greater or lesser degree, burdensome, and if what is at stake, in reality, is how to decide and with what priority to assign the resources which civil, political or social rights require in order to be satisfied, the political powers, by invoking the reserve of the possible, should always be able to demonstrate that they are making the maximum effort possible (in all fields: financial, personal, technological, etc.) and that they are giving priority to the most vulnerable groups ${ }^{77}$.

76 Cfr. Pertence apud Courtis, 2006, p. 117 ff.

77 We observe here a clear mandate directed at political power: if there is a more vulnerable group and resources are limited, possible policies should be directed, as a priority, towards the needs of the most vulnerable groups. In this context, the justification for the reserve of the possible entails a comparative judgment between what cannot be done and what is being done and always demands that it be demonstrated that maximum resources have been used: if there is a tax surplus, for example, the exposure of individuals to degrading conditions of life is not justified on the basis of the reserve of the possible. 
On the other hand, social rights are usually characterised as «vague» or indefinite rights. Thus, formulas such as the right to work would tell us very little in regard to the effective content of the right in question, as well as about what are obligations derived from it, for which reason social rights traditionally entail certain obligations of outcome, but leave the specific instruments of action to achieve them undefined. Civil and political rights, on the contrary, not only stipulate the outcome to be pursued, but also, and at the very least, indicate the means needed to avoid violating them.

Once again, the argument that points to the conclusion that social rights are rights that are difficult to protect is not supported. A certain degree of uncertainty, even in semantic terms, is inherent, not only to the legal language, but to the natural language itself. In the case of human and/or fundamental rights guaranteed in international treaties or constitutions, this uncertainty can arise from a demand derived from legal pluralism, since an excessive regulation of content and of consequential obligations of a right could cut off the democratic space from the social dialogue in regard to its scope ${ }^{78}$. Thus, it is not the case that the relative openness in the creation of social rights has the effect of making them unintelligible, nor is it the case that uncertainty involves an insurmountable barrier ${ }^{79}$.

Terms associated with traditional civil rights, such as honour, property and freedom of expression, are not less obscure than those commonly found within the sphere of social rights. All rights are provided with a «core of certainty» ${ }^{80}$, circumscribed by linguistic convention and hermeneutical practices that are not absolutely static, but instead, dynamic, and which, for this very reason, even contemplate, at any time, the possibility of interpretive development and of "grey areas». Within these contexts, if greater efforts made in legislative, jurisdictional and doctrinal activity are devoted to civil and political rights, this does not reflect a greater structural obscurity of social rights, but rather a deliberate and clearly ideological choice ${ }^{81}$.

Nothing prevents, therefore, development of criteria or indicators that outline a more appropriate meaning for a given social right. Rather, establishment of those parameters or indicators is, more than desirable, absolutely essential for monitoring compliance with obligations by the state on the subject of social rights, even for distinguishing, for instance, whether noncompliance of a duty arises from the lack of capability or from a true absence

78 In this sense, see M. Daly's report to the European Committee for Social Cohesion (Daly, 2003).

79 Cfr. Pisarello, 2007, p. 67.

80 In this sense, see Hart, 1963.

81 Cfr. Alexy, 1994, p. 490. 
of political will ${ }^{82}$; or to justify if, in a given legal system, a situation of regression, stagnation or progress on the subject of social rights is produced in a certain period of time.

Many of these criteria are what we call «soft law»; in other words, they merely constitute interpretive standards that, despite the legal structure they possess, are not mandatory in nature. However, their invocation by the intended beneficiaries of those rights and their consideration by the public authorities could help, in an effective way, to define the content of the social rights and the obligations originating from them, whether for public authorities or private individuals ${ }^{83}$.

In this sense, for instance, various courts have recognised the theory about the existence of minimum or essential frameworks on the subject of social rights, mandatory for public authorities as well as for private agents, from the perspective of international law or under frameworks protected by the constitutional codes themselves. Thus, the German Constitutional Court understood that, despite the fact that social rights were not explicitly granted in the Fundamental Law of Bonn, it is possible to derive a law of vital minimum from it, whether linked to the principle of the dignity of man ${ }^{84}$, or to that of material equality ${ }^{85}$, or the social state ${ }^{86}$. In a similar way, the Constitutional Court of Colombia deduced the right to a «vital minimum» from the text of the Constitution, which consisted of those goods and services needed for a life with dignity, above all in situations of urgency ${ }^{87}$, extending the scope of this «minimum» to the definition of rights as they pertain

82 In addition, inaccurate, incorrect or even falsified data tend to be determining elements in many violations of social rights. The existence or non-existence of sufficient resources for the financing of public policy and support of the principles of preparation, application and evaluation of policies guided by arguments such as reasonability and suitability are open questions subject to proof, including through the use of statistical data, and such arguments advanced would always be open to objection by others.

83 In this sense, see Pisarello, 2003 and 2007.

84 Art. 1: "Die Würde des Menschen ist unantastbar. Sie zu achten und zu schützen ist Verflichtung aller staatlichen Gewalt» ("The dignity of the human being is intangible. All public authorities are obligated to respect and protect it»).

85 Art. 2.2: "Jeder hat das Recht auf Leben und körperliche Unversehrtheit. Die Freiheit der Person ist unverletzlich. In diese Rechte darf nur auf Grund eines Gesetzes eingegriffen warden» («Each person has a right to life and physical integrity. Personal freedom is inviolable. Limitation of such rights cannot be done except through the law»).

86 Art. 20.1: «Die Bundesrepublik Deutschland ist ein demokratischer und sozialer Bundesstaat» ("The Federal Republic of Germany is a federal, democratic, and social state»). In this sense, see Alexy, 1994, pp. 414-494.

87 «The linkage between the concept of vital minimum and conditions of constitutional emergency was analysed by the Court, for instance, in its Judgment T-1150 de 2000 on forced displacement» (Ávila, 2002, p. 163). 
to health, housing and social security. Thus, neither the determination of the content of social rights, nor the stipulation of actions required to satisfy them, nor the identification of the individuals involved, are issues that fall outside the scope of the jurisdictional bodies.

We emphasise here that social rights obligate state authorities, whether through the executive, legislative, or even the judicial branch, but they can also obligate private parties, such as employers, service providers in the area of healthcare or education, and retirement and pension fund administrators. This linkage of private parties to fundamental rights can be the product of recognition expressed by the constituent legislator ${ }^{88}$ or it can even derive from different legal principles: from the prohibition against discrimination and good intention clauses up to the principle of protection of the weakest contractual party or of the social function of property ${ }^{89}$.

It is clear that obligations pertaining to social rights are also not projected on all private agents under all circumstances, because not all private individuals responsible for providing goods and services are in the same position of power and superiority in regard to third parties. Thus, the degree of linkage to observation and satisfaction of social rights by private parties is directly and proportionately related to their size, influence and resources ${ }^{90}$.

In summary, then, all fundamental human rights, whether civil, political or social, have a complex formulation, part positive and part negative, and

88 Art. 18.1 of the Portuguese Constitution, for example, establishes that «os preceitos constitucionais respeitantes aos direitos, liberdades e garantias são directamente aplicáveis e vinculam as entidades públicas e privadas» ("the constitutional precepts respecting rights, liberties, and guarantees are directly applicable and are binding upon public entities and private persons»). Art. 9 of the Spanish Constitution stipulates that "citizens and public authorities are subject to the Constitution and other bodies of laws».

89 In the United States, the system traditionally does not admit that private persons are bound to constitutionally-established fundamental rights, so that the system of law in the United States tends to impede the possibility of protecting fundamental rights within the scope of inter-subjective private relations. One exception has been admitted, which is expressly binding, not only on public authorities, but also on private agents in their inter-personal relations, referring specifically to the Thirteenth Amendment prohibiting slavery in the United States.

90 This is, for instance, the principle of linkage that is binding on private individuals, established by the Promotion of Equality and Prevention of Unfair Discrimination Act (2000), the South African law designed to promote equality and prevent unfair discrimination, is expressed in Art. 27.2: "The Minister must develop regulations in relation to this Act and other Ministers may develop regulations in relation to other Acts that require companies, closed corporations, partnerships, clubs, sports organisations, corporate entities and associations, where appropriate, in a manner proportional to their size, resources and influence, to prepare equality plans or abide by prescribed codes of practice or report to a body or institution on measures to promote equality». 
all are burdensome, in one way or another, as well as enforceable through the courts. We do not deny that, when dealing casuistically with a given right, certain elements can have a stronger symbolic effect than others, and that rights dealing with social benefits, which require greater financial expenditures, are more difficult to guarantee than other rights that do not require such costs, either because of financial and budgetary issues, or due to the conflictive nature with which the contributions and transfers of resources appear in a context of positional disputes. However, what we wish to emphasise is that none of these problems refers solely to social rights, but rather that such issues are related to all fundamental human rights within their social benefit dimension, whether they are civil, political or social rights - if, on one hand, no one affirms today that freedom of expression entails, in fact and within a democratic environment, free and unconditional access by anyone, in any circumstance, to the spaces in the communications media, radio, and television, neither can we affirm, for example, that the right to housing or to healthcare would entail the automatic and unconditional duty of public authorities to provide free housing or medications for all persons and under any circumstances ${ }^{91}$.

\section{FINAL CONSIDERATIONS: ON THE FUNDAMENTAL RIGHTS}

Despite the existence of various arguments denying the theory according to which social rights are structurally different from civil and political rights, that characterisation, from a dogmatic point of view, has had a strong impact on the issue of guardianship of social rights, which traditionally are seen as non-fundamental rights and thus with weaker protection, since they do not have available mechanisms of protection and guarantees analogous to those enjoyed by civil and political rights.

That approach implies, on the one hand, that social rights would appear as rights freely created by legislatures, that is, rights whose fulfilment would remain at the discretion of the authorities currently in power, who would decide what to do without our being able to impose greater limits or restrictions on that discretionary power, and, on the other hand, that social rights are not rights subject to the jurisdiction of the courts, in other words, they could not be invoked before the courts so that the particular jurisdictional entity would be in a position to render decisions establishing remedial measures when confronted with violations of such rights by political powers or private agents.

91 In this sense, see Pisarello, 2007. 
Initially, and on an axiological level, as we have already stated, what characterises a right as fundamental is, above all, its claim to protect interests or basic needs linked to the principle of real equality. It is the nature of those interests that enable them to be generalised to all persons, which, in short, makes a right inalienable and non-waivable, so that fundamental rights, human rights and individual rights have, from that perspective, analogous meanings.

From a dogmatic point of view, however, the situation looks a little more complex. Along general lines, we have a situation in which the rights referred to as fundamental are those to which greater relevance can be attributed within a given legal system, a relevance that can be measured from the inclusion of such rights into precepts of greater value under the scope of internal codes of law, such as constitutional codes or international treaties and covenants.

That being the case, it is possible that certain rights, which could be considered fundamental from an axiological point of view, are so from a dogmatic perspective as well, but that connection is not always made, so codes of law could incorporate, discriminatory or excluding interests and needs as fundamental, always the object of criticism from an axiological point of view ${ }^{92}$.

In any case, over and against the theory according to which social rights are weakly guarded rights, we state that it is not, in fact, the specific guarantees of that given right allow it to be classified as fundamental. On the contrary, it is precisely the inclusion of a right into the positive body of law as fundamental that requires legal operatives to maximise the mechanisms needed to guarantee and protect it. Therefore, if, from an axiological point of view, we can say that a certain equivalence exists between the expressions «fundamental rights», «human rights» and «individual rights», from a dogmatic perspective we can say that there is also a definite equivalence between the expressions «fundamental rights» and "constitutional rights» ${ }^{93}$.

92 Thus, for instance, the Constitution of the United States guarantees as fundamental the right to bear arms, while the European Constitutional Treaty (2004) establishes the clear priority of market freedom over social rights. In this sense, see Abramovich \& Courtis, 2002 and 2006; Pisarello, 2003 and 2007.

93 In this way, the potential absence of legislative and jurisdictional guarantees of a constitutional right - whether civil, political, or social - does not lead to the conclusion that it does not involve a fundamental right, but rather, on the contrary, it demonstrates the absence of compliance, or of insufficient compliance, with the implicit mandate for the behaviour of political and legal operatives, consistent with the legal standard. It is not the right which is not fundamental, but rather the political powers who engage in behaviour that distorts those rights or who fail to act, all of which de-legitimises this behaviour. In this sense, see Ferrajoli et al., 2001, p. 45. 
In current bodies of law, recognition of a right as fundamental, in and of itself, implies that we attribute to it a minimum content and, with that, the imposition of certain basic obligations on the public authorities, including (or primarily) obligations of non-discrimination, non-regression and progressivism. That does not really prevent the scope of certain laws from depending on that which the codes of law stipulate. There are constitutions, such as the Brazilian Constitution of 1988, which developed the content of social rights in a very meticulous way ${ }^{94}$; others offered only minimal regulation of social rights or relegated those rights to the scope of merely implicit rights ${ }^{95}$. Some constitutions stipulate in detail the obligations that recognition of a right entails for the public authorities and also for private agents, while others only allude to those obligations ${ }^{96}$.

If insertion into a constitutional text indicates the fundamental nature of a social right, it does not, however, constitute an essential requirement, given the principle of indivisibility and interdependency of all rights, since any constitution that includes the principle of equality in matters of basic, civil and political rights would raise, as an underlying principle, a mandate of generalisation that would require inclusion, at least indirectly, of social rights linked to them ${ }^{97}$. This has occurred, currently, in various codes of law that do not explicitly recognise social rights or grant them the status of fundamental rights. Thus, for example, in those codes of law, the right to decent housing has been logically inferred from other rights, such as that of the inviolability of the home, privacy, or private and family life ${ }^{98}$.

Il rights, not just the social, but also the political and those of participation, are rights created by legislatures in the sense that, for their full exercise, legislative intervention is essential in one way or another. The law, both by virtue of its formal legitimacy of the bodies from which it originates, as well as due to its ability to be generalised in scope, is a privileged source of legal

94 Also in this sense, the Italian Constitution of 1947 and that of Portugal of 1976. The South African Constitution of 1996 incorporates emerging social rights, which go beyond traditional rights, such as the right to water.

95 For example, the Constitution of the United States.

96 The Constitution of Ecuador (1996), for example, stipulates in Art. 96 that «at least thirty percent of the budget from current revenue of the central government is allocated to education and the eradication of illiteracy».

${ }_{97}$ Let us recall here the idea that all human rights are indivisible and inter-dependent.

98 In the case of López Ostra v. Spain (1994), the European Court of Human Rights (ECHR) considered that the absence of control by the public authorities on a polluting industry that negatively affected the health and safety of persons living in the immediate surrounding area constituted a violation of the right to privacy and family life. In this case, rights to the environment, health and shelter were implicated in an inter-related way. In this sense, see Pisarello, 2007. 
production in modern legal systems and constitutes a primary guarantee of the satisfaction of any rights ${ }^{99}$.

All rights - civil, political, and social - must be established by legislatures ${ }^{100}$, which can, of course, be varied in scope. Greater or lesser regulation certainly can strengthen or weaken the possibility that the rights in question can be legally claimed through the courts, but does not, in and of itself, prevent those rights from having, at least a minimum content, which lies beyond the reach of the authorities currently in power and is susceptible, for that very reason, to some type of jurisdictional guardianship, even in the absence of legislative regulation.

The Committee on Economic, Social, and Cultural Rights of the United Nations has maintained that public authorities have the duty to ensure, at any time and even in times of crisis or real economic and political difficulties, at least the essential content of those rights. Likewise, different codes of law recognise the duty of states to honour the minimum or essential content of rights recognised in constitutions or international covenants and treaties ${ }^{101}$,

99 In this sense, see Sheinin apud Eide, 1995, p. 54 ff., and Liebenberg apud Eide, 1995, p. $79 \mathrm{ff}$.

100 Thus, for instance, the exercise of the right to healthcare presupposes laws that avoid discrimination against access to basic healthcare services or that intervene in the market to ensure basic drugs at a low cost.

101 For example, Art. 19 of the Fundamental Law of Bonn (1949): «1) Soweit nach diesem Grundgesetz ein Grundrecht durch Gesetz oder auf Grund eines Gesetzes eingeschränkt werden kann, muß das Gesetz allgemein und nicht nur für den Einzelfall gelten. Außerdem muß das Gesetz das Grundrecht unter Angabe des Artikels nennen. 2) In keinem Falle darf ein Grundrecht in seinem Wesensgehalt angetastet warden» («1) When, in accordance with the present Fundamental Law, a fundamental right can be restricted by law or by virtue of a law, this should be enforced in a general way, and not only for a specific case. A fundamental right, in addition, should be stated in the law, with a reference to the specific article in question. 2) This should not, in the instant case or in any case whatsoever, have any effect as to whether a violation of the substance of a fundamental right has been committed»), as Art. 18 of the Portuguese Constitution (1976) establishes: «1. Os preceitos constitucionais respeitantes aos direitos, liberdades e garantias sáo directamente aplicáveis e vinculam as entidades públicas e privadas. 2. A lei só pode restringir os direitos, liberdades e garantias nos casos expressamente previstos na Constituição, devendo as restriçōes limitarse ao necessário para salvaguardar outros direitos ous interesses constitucionalmente protegidos. 3. As leis restritivas de direitos, liberdades e garantias têm de revestir carácter geral e abstracto e não podem ter efeito retroactivo nem diminuir a extensão e o alcance do conteúdo essencial dos preceitos constitucionais» («1. Constitutional percepts in observance of rights, liberties, and guarantees are directly applicable and are binding on public and private entities. 2. The law may only restrict rights, liberties and guarantees in cases expressly provided in the Constitution, restrictions in this regard limited only to what would be necessary to safeguard other rights or constitutionally protected interests. 3. Laws restricting rights, liberties and guarantees should adopt a general and abstract nature and may not have retroactive effect or diminish the scope and reach of the essential content of constitutional precepts»). 
content that is dependent upon the context in which such rights are applied and that allows historic rights to be updated on an ongoing basis ${ }^{102}$.

In any case, that minimum will always be a barrier that cannot be crossed, which requires a permanent delineation demanding real integration between justice and politics, and between judges and legislators. What we maintain is that constitutional recognition of social rights entails, under any circumstances and even in times of economic crisis, an untouchable core by the existing authorities, even for jurisdictional bodies; as a result, none of those powers can fail to recognise them and, therefore, all persons must be assured of them, especially those who find themselves in more vulnerable positions ${ }^{103}$.

\section{REFERENCES}

Abramovich, V., \& Courtis, C. (2002). Los derechos sociales como derechos exigibles. Madrid: Trotta.

Abramovich, V., \& Courtis, C. (2006). Los derechos sociales en el debate democrático. Madrid: Bomarzo.

Alexy, R. (1994). Teoría de los derechos fundamentales. Madrid: Centro de Estudios Constitucionales.

Añón, M. J., \& Añón, J. G. (2003). Lecciones de derechos sociales. Valencia: Tirant Lo Blanch.

Ávila, J. T. (2002). El minimo vital en la jurisprudencia de la corte constitucional. Bogotá: Cinep-Diakonia.

Balibar, É. (1992). Les frontières de la démocratie. Paris: La Découverte.

Barcellos, A. P. (2002). A eficácia jurídica dos princípios constitucionais: o princípio da dignidade da pessoa humana. Rio de Janeiro: Renovar.

Canotilho, J. J. (1999). Direito constitucional e teoria da constituição. Coimbra: Almedina.

Carbonell, M., Parcero, J. A., \& Vázquez, R. (2001). Derechos sociales y derechos de las minorías. Mexico City: Porruá - Unam.

102 The essential content of those rights does not presuppose an abstract or transcendent understanding: the border between what we may consider essential or basic and what we may characterise as additional, or non-essential, is always moveable, historic, and open.

103 Thus, according to Langford (apud Pisarello, 2007, p. 86), "In essence, not only would there exist a minimum or essential content attributable to each civil, political, or social right in an isolated way, but also a minimum population, comprised of collective groups under conditions of greater vulnerability, whose protection, above all in times of crisis, should be established as a priority by the public authorities». 
Carter, I. (2005). La libertà eguale. Milano: Feltrinelli.

Castel, R. (1995). Les métamorphoses de la question sociale: une chronique du salariat. Paris: Fayard.

Castro, J. L. (1988). La tutela constitucional de los derechos sociales. Madrid: Centro de Estudios Constitucionales.

Courtis, C. (2006). Ni un paso atrás: la prohibición de regresividad en materia de derechos sociales. Buenos Aires: Cels.

Craven, M. (1995). The international covenant on economic, social and cultural rights: A perspective on its development. Oxford: Clarendon.

Daly, M. (2003). Acesso aos direitos sociais na Europa: relatório do Conselho da Europa. Lisboa: Ministério da Segurança Social e do Trabalho.

Dean, H. (1997). The juridification of welfare: Strategies of discipline and resistance. In A. Kjønstad \& J. V. Wilson (Eds.), Law, power and poverty. Bergen: Crop.

De La Torre, H. M. (1996). Derechos humanos: dignidad y conflicto. Mexico City: Universidad Interamericana.

Delfino, D. (2007). A Rússia antes da revolução. História Viva - Grandes Temas, 18.

Dworkin, R. (2005). A virtude soberana: a teoria e a prática da igualdade. São Paulo: Martins Fontes.

Eide, A. (1995). Economic, social and cultural rights. Dordrecht: M. Nijhoff.

Esping-Andersen, G. (1998). The three worlds of welfare capitalism. Princeton: Princeton University.

Fabre, C. (2000). Social rights under the Constitution. Oxford: Clarendon.

Ferrajoli, L. (1990). Diritto e ragione. Roma: Laterza.

Ferrajoli, L. (2005). Los fundamentos de los derechos fundamentales. Madrid: Trotta.

Ferrajoli, L. (2006). Garantismo: una discusión sobre democracia y derecho. Madrid: Trotta.

Ferrajoli, L. et al. (2001). Los fundamentos de los derechos fundamentales. Madrid: Trotta.

Flores, J. H. (2000). El vuelo de Anteo: derechos humanos y crítica de la razón liberal. Bilbao: Desclée de Brouwer.

Fontana, J. (1982). Historia: análisis del pasado y proyecto social. Barcelona: Crítica.

Franco, A. (2002). Pobreza \& desenvolvimento local. Brasília: Aed.

Gallardo, H. (2000). Politica y transformación social: discusión sobre derechos humanos. Quito: Tierra Nueva.

Giddens, A. (1990). Sociology. Oxford: Polity.

Graham, M. A., \& Vega, J. C. (1996). Jerarquía constitucional de los tratados internacionales. Buenos Aires: Astrea. 
Gutiérrez, I. (2005). Dignidad de la persona y derechos fundamentales. Madrid: Marcial Pons.

Habermas, J. (2005). Facticidad y validez: sobre el derecho y el Estado democrático de derecho en términos de teoría del discurso. Madrid: Trotta.

Hart, H. (1963). El concepto del derecho. Buenos Aires: Abeledo-Perrot.

Holmes, S., \& Sunstein, C. (1999). The cost of rights: Why liberty depends on taxes. New York: Norton.

Ibáñez, A. (1996). Corrupción y Estado de derecho. Madrid: Trotta.

Kliksberg, B. (1997). O desafio da exclusão: para uma gestão social eficiente. São Paulo: Fundap.

López, M. C. (2002). Derecho del trabajo e ideología: medio siglo de formación ideológica del derecho de trabajo en España (1873-1923). Madrid: Tecnos.

Luño, A. E. (1999). Derechos humanos, Estado de derecho y Constitución. Madrid: Tecnos.

Marín, A. O. (1996). Estado social y crisis económica. Madrid: Complutense.

Marshall, T., \& Bottomore, T. (1998). Ciudadanía y clase social. Madrid: Alianza.

Martin, C., Rodríguez, D., \& Guevara, J. (2004). Derecho internacional de los derechos humanos. Mexico City: Fontamara.

Martín, C. C. (2006). Teoría constitucional de la solidaridad. Madrid: Marcial Pons.

Martínez, G. P. (1995). Curso de derechos fundamentales: teoría general. Madrid: Universidad Carlos III.

Martínez, G. P. (1988). Escritos sobre derechos fundamentales. Madrid: Eudema.

Marx, K. (1972). La guerre civile en France. Paris: Sociales.

Nino, C. S. (1989). Ética y derechos humanos. Barcelona: Ariel.

Oliveira, M. V. (1989). Previdência social. Rio de Janeiro: Freitas Bastos.

Papacchini, A. (2005). Filosofía y derechos humanos. Cali: Universidad del Valle.

Pereira, F. H., \& Dias, M. T. (2008). Cidadania e inclusão social. Belo Horizonte: Fórum.

Pisarello, G. (2003). El Estado social como Estado constitucional: mejores garantías, más democracia. In V. Abramovich, M. J. Añón, \& C. Courtis (Coords.), Derechos sociales: instrucciones de uso. Mexico City: Fontamara.

Pisarello, G. (2007). Los derechos sociales y sus garantías. Madrid: Trotta.

Reis, J. R. (2005). A vinculação dos particulares aos direitos fundamentais nas relaçóes interprivadas: breves consideraçóes. In R. G. Leal \& J. R. Reis (Coords.), Direitos sociais e politicas públicas: desafios contemporâneos. Santa Cruz do Sul: Edunisc.

Ritter, G. A. (1999). Storia dello Stato sociale. Roma: Laterza.

Roman, D. (2002). Le droit public face à la pauvreté. Paris: Lgdj. 
Santos, B. S. (2005). A globalização e as ciências sociais. São Paulo: Cortez.

Sarlett, I. W. (2002). Dignidade da pessoa humana e direitos fundamentais na Constituição federal de 1988. Porto Alegre: Livraria do Advogado.

Sen, A. (2006). El valor de la democracia. Barcelona: Cultural.

Serge, V. (1993). O ano I da revolução russa. São Paulo: Ensaio.

Silva, R. M. (2002). Derecho internacional de los derechos humanos. Mexico City: Unam. Tocqueville, A. (1994). Recuerdos de la revolución de 1848. Madrid: Trotta.

Vuolo, R. (2004). La pobreza ... de la politica contra la pobreza. Buenos Aires: Ciepp.

\section{Riassunto}

Dal punto di vista del diritto internazionale, quello che stiamo cercando di sviluppare in questo articolo consiste nell'esporre alcune premesse per delineare un (nuovo) orientamento allo studio dei diritti sociali fondamentali. Se pensiamo al primato assoluto della vita umana, una vita che - per essere intesa come tale - deve essere vissuta con dignità, dobbiamo pensare alla vita da un punto di vista materiale e, quindi, in uno stato di priorità rispetto ai cosiddetti diritti "sociali», dal momento che i diritti sociali (economici, sociali e culturali) indirizzano le esigenze di base per la vita e la dignità umana, come il cibo, la salute, la casa, il lavoro, l'istruzione e l'acqua. In base a quanto detto, diventa molto chiaro che la materialità della dignità umana si basa sul cosiddetto "minimo esistenziale», il nocciolo duro dei diritti sociali, in modo tale che i diritti sociali siano autentici (veri) diritti umani fondamentali. Il riconoscimento dei diritti sociali non può essere, quindi, un semplice elenco di buone intenzioni da parte dello Stato. I diritti sociali sono diritti fondamentali, che valgono per tutti gli uomini, possono essere esercitati da chiunque e sono essenziali per la vita e la dignità umana. Quello che stiamo cercando di perseguire attraverso questo scritto, quindi, è il tentativo di far luce su quanto i diritti sociali siano fondamentali diritti umani nel diritto internazionale.

Parole chiave: Diritti fondamentali, Diritti sociali, Diritti umani, Diritto internazionale, Premesse.

How to cite this Paper: Schwarz, R. G. (2016). On human rights: Premises for a new approach to fundamental social rights [Sui diritti umani: premesse per un nuovo approccio ai diritti sociali fondamentali]. Journal of Educational, Cultural and Psychological Studies, 13, 25-62. doi: 10.7358/ecps-2016-013-garc

\footnotetext{
ECPS Journal - 13/2016

http://www.ledonline.it/ECPS-Journal/
} 